Pulmonary lymph flow and the uptake of liquid from the lungs of the lamb at the start of breathing. J. Physiol. (London), 193: 1 (1967).

19. Hyman, A. L.: Effects of large increases in pulmonary blood flow on pulmonary venous pressure. J. Appl. Physiol., 27: 179 (1969).

20. Hyman, A. L. and Kadowitz, P. J.: Effects of alveolar and perfusion hypoxia and hypercapnia on pulmonary vascular resistance in the lamb. Am. J. Physiol., 228: 397 (1975)

21. Inoue, H., Inoue, C., and Hildebrandt, J.: Vascular and airway pressures, and interstitial edema affect peribronchial fluid pressure. J. Appl. Physiol., 48: $177(1980)$

22. Kato, M. and Staub, N. C.: Response of small pulmonary arteries to unilobar hypoxia and hypercapnia. Circ. Res., 19: 426 (1966).

23. Kuida, H., Tsagaris, T. J., and Hecht, H. H.: Evidence for pulmonary venoconstriction in brisket disease. Circ. Res., 12: 182 (1963).

24. Landolt, C. C., Matthay, M., and Staub, N. C.: Lung resection, increased blood flow and high pressure in sheep. Failure to detect pore stretching or high linear flow injury. Microvasc. Res., 20: 117 (1980).

25. Malik, A. B. and Kidd, B. S. L.: Independent effects of changes in $\mathrm{H}^{+}$and $\mathrm{CO}_{2}$ concentrations on hypoxic pulmonary vasoconstriction. J. Appl. Physiol., 34: 318 (1973).

26. Malik, A. B. and Kidd, B. S. L.: Pulmonary arterial wedge and left atrial pressures and the site of hypoxic pulmonary vasoconstriction. Respiration, 33: 123 (1976).

27. Mellins, R. B., Levine, O. R., Skalak, R., and Fishman, A. F. Interstitial pressure of the lung. Circ. Res., 24: 197 (1969).

28. Mitzner, W. and Sylvester, J. T.: Hypoxic vasoconstriction and fluid filtration in pig lungs. J. Appl. Physiol., 51; 1065 (1981)

29. Morgan, B. C., Church, S. C., and Guntheroth, W. G.: Hypoxic constriction of pulmonary artery and vein in intact dogs. J. Appl. Physiol, 25:356 (1968).

30. Nicolaysen, G., Nicolaysen, A., and Staub, N. C.: A quantitative radioautographic comparison of albumin concentration in different sized lymph vessels in normal mouse lungs. Microvasc. Res., 10: 138 (1975).

31. Pearce, M. L., Yamashita, J., and Beazell, J.: Measurement of pulmonary edema. Circ. Res., 16; 482 (1965).

32. Rivera-Estrada, C., Saltzman, P. W., Singer, D., and Katz, L. N.: Action of hypoxia on the pulmonary vasculature. Circ. Res., 6: 10 (1958).

33. Roos, P. J., Albertine, K. H., Weiner-Kronish, J. P., Culver, P. L., and Staub, N. C.: Removal of portal system contribution to caudal mediastinal node $(\mathrm{CMN})$ efferent lymph in anesthetized sheep. Physiologist, 25: 311 (1981).

34. Rudolph, A. M.: Congenital Diseases of the Heart: Clinical-Physiologica Considerations in Diagnosis and Management. pp. 139-149 (Chicago, Year Book Medical Publishers, 1974).

35. Rudolph, A. M. and Yuan, S.: Response of the pulmonary vasculature to hypoxia and $\mathrm{H}^{+}$ion concentration changes. J. Clin. Invest., 45: 399 (1966).
36. Snedecor, G. W. and Cochran, W. G.: Statistical Methods, Ed. 6, pp. 91-119. (Ames Iowa State University Press, 1972).

37. Stahlman, M., Gray, J., Young, W. C., and Shepard, F. M.: Cardiovascular response of the neonatal lamb to hypoxia and hypercapnia. Am. J. Physiol., 213: 899 (1967)

38. Stalcup, S. A. and Mellins, R. B.: Mechanical forces producing pulmonary edema in acute asthma. N. Eng. J. Med., 297: 592 (1977).

39. Staub, N. C.: Pulmonary Edema. Physiol. Rev., 54: 678 (1974).

40. Staub, N. C., Bland, R. D., Brigham, K. L., Demling, R. H., Erdmann, A. J III, and Woolverton, W. C.: Preparation of chronic lung lymph fistulas in sheep. J. Surg. Res., 19: 315 (1975).

41. Vaughan, T. R., Erdmann, A. J., III, Brigham, K. L., Woolverton, W. C., Weidner, W. J., and Staub, N. C.: Equilibration of intravascular albumin with lung lymph in unanesthetized sheep. Lymphology, 12: 217 (1979).

42. Viswanathan, R., Subrumanian, S., and Radha, T. G.: Effect of hypoxia on regional lung perfusion by scanning. Respiration, 37: 142 (1979).

43. Vreim, C. E. and Staub, N. C.: Indirect and direct pulmonary capillary blood volume in anesthetized open-thorax cats. J. Appl. Physiol., 34:452 (1973).

44. Vreim, C. E., Snasnall, P. D., Demling, R. H., and Staub, N. C.: Lung lymph and free interstitial fluid protein composition in sheep with edema. Am.J. Physiol., 230: 1650 (1976).

45. Warren, M. F., Peterson, D. K., and Drinker, C. K.: The effects of heightened negative pressure in the chest, together with further experiments upon anoxia in increasing the flow of lung lymph. Am. J. Physiol., 137: 641 (1942).

46. Whayne, T. F. Jr. and Severinghaus, J. W.: Experimental hypoxic pulmonary edema in the rat. J. Appl. Physiol., 25: 729 (1968)

47. The authors wish to thank R. B. Goldberg and T. M. Chou for their technical assistance, $\mathrm{C}$. Oliphant and $\mathrm{M}$. Biagini for typing the manuscript and $\mathrm{M}$. H. Briscoe for drawing the figures.

48. Requests for reprints should be addressed to: Thomas N. Hansen, Department of Pediatrics, Baylor College of Medicine, 1200 Moursund Ave., Houston, TX 77030

49. Work presented in this paper was supported in part by National Heart, Lung and Blood Institute (NHLBI) Pulmonary Specialized Center of Research (SCOR) Grant HL 19185, and by U.S. Public Health Service Program Project Grants HL/HD 24056 and HL 25816. R. D. Bland did part of this work during his tenure as an Established Investigator of the American Heart Association. T. N. Hansen and T. A. Hazinski were Trainees supported by NHLBI Pulmonary Faculty Training Grant HL 07159. C. M. Haberkern received support from Grant HD 05709 awarded by the Institute for Child Health and Human Development of the National Institutes of Health. 50. Received for publication January 10,1983.

51. Accepted for publication June 3, 1983 .

\title{
Maternal Corticosteroid Therapy and the Fetal Brain in Experimental Hyaline Membrane Disease
}

\author{
S. M. SUMI, ${ }^{(28)}$ WILLIAM E. TRUOG III, AND DALE M. KESSLER
}

Laboratory of Neuropathology, Department of Pathology, Division of Neurology, Department of Medicine and the Child Development and Mental Retardation Center, University of Washington School of Medicine [S. M. S.] and Department of Pediatrics and the Child Development and Mental Retardation Center, University of Washington School of Medicine [W.E. T., D. M. K.J Seattle, Washington, USA

\section{Summary}

The possible acute deleterious effects of maternal glucocorticoid administration on the fetal nervous system and the pathologic significance of sudanophilic lipids in glial cells were studied in the premature pigtail monkey (macaca mulatta). At 72,48 , and $24 \mathrm{~h}$ before delivery at $135 \pm 1 \mathrm{~d}$ gestation, dams were treated with either $4 \mathrm{mg}$ dexamethasone or saline. After delivery, respiratory function of each fetus was determined and supported. The animals were sacrificed at $3 \mathrm{~h}$ of age.

Brain weights were similar in the two groups. Dark, shrunken, pyknotic neurons were present in the hippocampus of three treated and two control animals. Lipid-containing glial cells were present in all animals. Neither appeared to be related to steroid treatment or to the degree of respiratory distress.

We conclude that short-term glucocorticoid therapy in doses 
analogous to those used in humans for the prevention of hyaline membrane disease does not result in acute neuronal damage. Sudanophilic lipid accumulation in glial cells is not always abnormal and must be distinguished from glial fatty metamorphosis.

\section{Abbreviations}

HMD, hyaline membrane disease

$\mathrm{RD}$, respiratory distress

SAM, surface active material

Antenatal glucocorticoid treatment reduces the incidence of HMD in premature infants (15) and accelerates the appearance of pulmonary SAM in experimental animals (7). The expanding use of corticosteroids in the perinatal period has raised serious concerns regarding possible deleterious effects on the developing brain. Reports in human infants $(8,24,25)$ have been inconclusive.

Another controversy regarding the immature brain has been the interpretation of sudanophilic lipid-containing glial cells (not macrophages) which are almost constantly found in the unmyelinated telencephalic white matter of human premature infants. Some investigators $(14,18,19)$ have considered these cells to be pathologic, the result of hypoxia or other stresses in the perinatal period, and termed "glial fatty metamorphosis" (14). Others (17, 26 ) regard them as nonpathologic, but the normal precursors of myelination.

During the study of maternal dexamethasone administration on experimental HMD in the premature monkey (12), we had the opportunity to examine the brains of these animals for evidence of acute neuronal and glial damage which might be attributed to the glucocorticoid, and to determine the relation between sudanophilic lipid accumulation and the degree of hypoxia.

\section{MATERIALS AND METHODS}

Details of the experimental procedure have already been reported (12). Briefly, at 72, 48, and $24 \mathrm{~h}$ before delivery by caesarian section at $135 \pm 1$ d gestation, each dam received an intramuscular injection $(0.5 \mathrm{ml} /$ dose $)$ from a numbered vial containing either dexamethasone $(4 \mathrm{mg} / \mathrm{ml})$ or saline. There were 12 animals in each group.

After delivery, each baby monkey was resuscitated as necessary, a tracheostomy was performed, and the animal ventilated on a small animal ventilator (Harvard Apparatus, Millis, MA) at $30-40$ breaths/min and administered $100 \%$ oxygen. Arterial blood gas tensions and $\mathrm{pH}$ were monitored, and $\mathrm{PaO}_{2}, \mathrm{PaCO}_{2}$, and $\mathrm{pH}$ were maintained in the normal ranges. Each animal was sacrificed at $3 \mathrm{~h}$ of age by IV injection of sodium pentobarbital.

A RD score for each animal was determined on the basis of 1) the degree of respiratory distress noted before tracheostomy and mechanical ventilation, 2) the $\mathrm{PaO}_{2}$ at $2 \mathrm{~h}$ of age and 3) the interpretation of a chest radiograph at $2 \frac{1 / 2}{h}$ of age. Severe HMD corresponded to a score of 1 , whereas the maximum possible score of 9 indicated normal pulmonary function by all three assessment measures.

Immediately after sacrifice the lungs, liver, and brain were removed in that order, and the brain was weighed and then fixed by immersion in buffered formaldehyde. After fixation for 7-10 $\mathrm{d}$, the brain was reweighed. The cerebral hemispheres were cut coronally, and the brainstem and cerebellum horizontally. Multiple sections of the cerebrum, brainstem, and cerebellum were embedded in gelatin, sectioned on a freezing microtome, and stained with oil-red-0 and hematoxylin for sudanophilic lipids and myelin (3). Additional sections of the cerebrum (including the hippocampus) and of the cerebellum were embedded in paraffin and stained with hematoxylin and eosin, then examined for shrunken, darkly staining or eosinophilic neurons with pyknotic nuclei.
The total number of lipid-containing cells in each of the structures in the corpus callosum and fornix (anterior and middle portions), cingulum, parietal lobe white matter, optic tract or chiasm, posterior limb of internal capsule, and visual radiation were recorded as follows:

0, no lipid-containing cells

$0.5,1-9$ lipid-containing cells per high power field

$1,10-20$ lipid-containing cells per high power field

2, 21-30 lipid-containing cells per high power field

3, 31-40 lipid-containing cells per high power field

4 , more than 40 lipid-containing cells per high power field

The amount of lipid accumulation for each animal was expressed as the total of the scores in each of these sites, with the minimum possible being 0 and the maximum 44 .

The degree of myelination in the same sites was estimated as suggested by Gilles et al. (9): 0 , no myelin; 1, myelin visible microscopically only; 2 , myelin just visible grossly; and 3 , grossly obvious myelin. The degree of myelination for each animal was expressed as a total of the scores in each of these sites, with the minimum possible score being 0 and the maximum 33 .

\section{RESULTS}

The extent of HMD expressed as RD score, the brain weights, the presence or absence of shrunken and pyknotic neurons in the hippocampus and cerebellum, the numbers of sudanophilic lipid-containing glial cells, and the degree of myelination are summarized in Tables 1 and 2.

Brain weight. The fresh brain weight in the treated animals ranged from $34.0-57.5 \mathrm{~g}$ with a mean of $46.4 \pm 7.9 \mathrm{~g}$ (11 animals). In the control group, the range was from $37.0-53.2 \mathrm{~g}$ with a mean of $44.8 \pm 5.1 \mathrm{~g}(11$ animals $)$. There was no significant difference between the two groups, and there was no correlation between brain weight and RD score.

Shrunken, pyknotic neurons in the hippocampus and cerebellum. Grossly, no abnormality was seen in any of the brains externally or after sectioning. Sections of both the hippocampus and the cerebellum stained by hematoxylin and eosin were available for 20 animals (11 treated, nine untreated) and hippocampal sections only for the other three animals. No definite abnormality was found in the cerebellum of any of the animals, particular attention being paid to the Purkinje cells.

Shrunken, darkly stained, pyramidal neurons were present in the hippocampus of three treated and two control animals. Not only were the cell bodies of these neurons shrunken and darkly staining, but their nuclei were pyknotic and the nucleoli could not be identified. They were located most commonly in the footplate of the cornu ammonis or in the subiculum. Neurons in the other cortical regions or in the basal ganglia and thalamus, which were also included in the same section, showed no such change. The RD scores of these animals were 4,6 , and 9 in the treated group, and 3 and 4 in the untreated. In both groups there were other animals with equally low or lower RD scores with no histologic abnormality.

Sudanophilic lipid accumulation and the degree of myelination. There were 19 animals in which this could be adequately evaluated (eight controls, 11 treated). The lipid-containing cells were present in the white matter and all appeared to be glial. Many of these cells were spindle-shaped or had multiple cellular processes with the lipid droplets outlining these processes. No macrophagelike, large, round, lipid-filled cells, or focal areas of necrosis of the white matter were found in any of the animals.

Although the total number of lipid-containing cells varied somewhat among the animals, such cells were present in at least some of the sites examined in all the animals in small numbers; these varied from a score of $0.5-1$, and most frequently were found in the corpus callosum. The range of total numbers of these lipid-containing cells in the various sites was greater in the treated animals $(2.5-8)$ than in the controls $(5-7.5)$; but the 
Table 1. Brain findings in dexamethasone-treated animals

\begin{tabular}{|c|c|c|c|c|c|c|c|c|c|c|c|c|c|c|c|c|}
\hline \multirow[b]{3}{*}{$\begin{array}{c}\text { Animal } \\
\text { no. }\end{array}$} & \multirow[b]{3}{*}{$\begin{array}{l}\text { RD } \\
\text { score }\end{array}$} & \multicolumn{2}{|c|}{$\begin{array}{l}\text { Brain weight } \\
\qquad(\mathrm{Gm})\end{array}$} & \multicolumn{2}{|c|}{$\begin{array}{c}\text { Abnormal } \\
\text { neurons }\end{array}$} & \multicolumn{11}{|c|}{ Degree of myelination (M) and lipid accumulation (L); (M/L) } \\
\hline & & \multirow[b]{2}{*}{ Fresh } & \multirow[b]{2}{*}{ Fixed } & \multirow[b]{2}{*}{$\begin{array}{l}\text { Hippo- } \\
\text { campus }\end{array}$} & \multirow[b]{2}{*}{$\begin{array}{c}\text { Cere- } \\
\text { bellum }\end{array}$} & \multicolumn{2}{|c|}{ Corpus callosum } & \multicolumn{2}{|c|}{ Fornix } & \multirow[b]{2}{*}{ Cingulum } & \multirow[b]{2}{*}{$\begin{array}{c}\text { Parietal } \\
\text { lobe }\end{array}$} & \multirow[b]{2}{*}{$\begin{array}{l}\text { Internal } \\
\text { capsule }\end{array}$} & \multirow[b]{2}{*}{$\begin{array}{l}\text { Optic } \\
\text { tract }\end{array}$} & \multirow[b]{2}{*}{$\begin{array}{l}\text { Visual } \\
\text { radiation }\end{array}$} & \multicolumn{2}{|c|}{ Total } \\
\hline & & & & & & Anterior & Middle & Anterior & Middle & & & & & & $\begin{array}{l}\text { Myeli- } \\
\text { nation }\end{array}$ & Lipid \\
\hline 7181 & 6 & $\ldots *$ & 50.0 & + & $\mathrm{N}$ & $0 / 0$ & & $0 / 0$ & $\cdots$ & $0 / 0$ & & $1 / 1$ & & $0 / 1$ & $\ldots$ & \\
\hline 7195 & 4 & 55.7 & 67.8 & + & $\mathrm{N}$ & $0 / 1$ & $0 / 1$ & $0 / 0$ & $0 / 1$ & $0 / 0$ & $0 / 1$ & $0 / 1$ & $1 / 2$ & $0 / 1$ & 1 & 8 \\
\hline 7196 & 3 & 34.0 & 43.8 & $\mathrm{~N}$ & $\mathrm{~N}$ & $0 / 1$ & $0 / 1$ & $0 / 0$ & $0 / 1$ & $0 / 0$ & $0 / 1$ & $0 / 1$ & $1 / 0$ & $0 / 1$ & 1 & 6 \\
\hline 7198 & 5 & 47.0 & 64.7 & $\mathrm{~N}$ & $\mathrm{~N}$ & $0 / 0$ & $0 / 1$ & $0 / 0$ & $0 / 1$ & $0 / 0$ & $0 / 1$ & $1 / 0$ & $2 / 0$ & $0 / 1$ & 3 & 4 \\
\hline 7233 & 4 & 49.7 & 62.1 & $\mathrm{~N}$ & $\mathrm{~N}$ & $0 / 0.5$ & $0 / 0.5$ & $0 / 0$ & $0 / 0.5$ & $0 / 0.5$ & $0 / 1$ & $1 / 1$ & $1 / 1$ & $0 / 1$ & 2 & 6 \\
\hline 7250 & 2 & 40.8 & 46.6 & $\ldots$ & $\ldots$ & $0 / 1$ & $0 / 0.5$ & $0 / 0$ & $0 / 0$ & $0 / 0$ & $0 / 0$ & $1 / 0$ & $2 / 1$ & $0 / 0$ & 3 & 2.5 \\
\hline 7249 & 8 & 50.0 & 59.0 & $\mathrm{~N}$ & $\mathrm{~N}$ & $0 / 1$ & $0 / 1$ & $0 / 1$ & $0 / 1$ & $0 / 0$ & $0 / 1$ & $1 / 1$ & $2 / 1$ & $0 / 0$ & 3 & 7 \\
\hline 7172 & 6 & 40.7 & 52.8 & $\mathrm{~N}$ & $\mathrm{~N}$ & $0 / 1$ & $0 / 1$ & $0 / 1$ & $0 / 1$ & $0 / 0$ & $0 / 1$ & $0 / 1$ & $1 / 1$ & $0 / 1$ & 1 & 8 \\
\hline 7224 & 9 & 57.5 & 66.0 & + & $\mathrm{N}$ & $0 / 0$ & $0 / 0.5$ & $0 / 0$ & $0 / 0.5$ & 0.0 & $0 / 0$ & $1 / 0$ & $1 / 1$ & $0 / 1$ & 2 & 3 \\
\hline 7225 & 7 & 35.0 & 50.2 & $\mathrm{~N}$ & $\mathrm{~N}$ & $0 / 1$ & $0 / 0.5$ & $0 / 0.5$ & $0 / 1$ & $0 / 0.5$ & $0 / 1$ & $1 / 1$ & $1 / 2$ & $0 / 1$ & 2 & 8.5 \\
\hline 7241 & 5 & 45.1 & 56.6 & $\mathrm{~N}$ & $\ldots$ & $0 / 1$ & $0 / 1$ & $0 / 0$ & $0 / 1$ & $0 / 1$ & $1 / 1$ & $2 / 1$ & $2 / 1$ & $0 / 1$ & 5 & 8 \\
\hline 7245 & 7 & 54.0 & 51.5 & $\mathrm{~N}$ & $\mathrm{~N}$ & $0 / 1$ & $0 / 1$ & $0 / 0$ & $0 / 1$ & $0 / 0$ & $0 / 1$ & $1 / 1$ & $2 / 1$ & $0 / 1$ & 3 & 7 \\
\hline
\end{tabular}

Table 2. Brain findings in control animals

\begin{tabular}{|c|c|c|c|c|c|c|c|c|c|c|c|c|c|c|c|c|}
\hline \multirow[b]{3}{*}{$\begin{array}{c}\text { Animal } \\
\text { no. }\end{array}$} & \multirow[b]{3}{*}{$\begin{array}{l}\mathrm{RD} \\
\text { score' }\end{array}$} & \multicolumn{2}{|c|}{$\begin{array}{l}\text { Brain weight } \\
\qquad(\mathrm{Gm})\end{array}$} & \multicolumn{2}{|c|}{$\begin{array}{c}\text { Abnormal } \\
\text { neurons }\end{array}$} & \multicolumn{11}{|c|}{ Degree of myelination $(\mathrm{M})$ and lipid accumulation $(\mathrm{L}) ;(\mathrm{M} / \mathrm{L})$} \\
\hline & & \multirow[b]{2}{*}{ Fresh } & \multirow[b]{2}{*}{ Fixed } & \multirow[b]{2}{*}{$\begin{array}{l}\text { Hippo- } \\
\text { campus }\end{array}$} & \multirow[b]{2}{*}{$\begin{array}{c}\text { Cere- } \\
\text { bellum }\end{array}$} & \multicolumn{2}{|c|}{ Corpus callosum } & \multicolumn{2}{|c|}{ Fornix } & \multirow[b]{2}{*}{ Cingulum } & \multirow[b]{2}{*}{$\begin{array}{l}\text { Parietal } \\
\text { lobe }\end{array}$} & \multirow[b]{2}{*}{$\begin{array}{l}\text { Internal } \\
\text { capsule }\end{array}$} & \multirow[b]{2}{*}{$\begin{array}{l}\text { Optic } \\
\text { tract }\end{array}$} & \multirow[b]{2}{*}{$\begin{array}{l}\text { Visual } \\
\text { radiation }\end{array}$} & \multicolumn{2}{|c|}{ Total } \\
\hline & & & & & & Anterior & Middle & Anterior & Middle & & & & & & $\begin{array}{l}\text { Myeli- } \\
\text { nation }\end{array}$ & Lipid \\
\hline 7182 & 5 & $\ldots *$ & 61.7 & $\mathrm{~N}$ & $\mathrm{~N}$ & $0 / 1$ & $0 / 0$ & $0 / 0$ & $0 / 0$ & $0 / 0$ & $0 / 1$ & $0 / 1$ & & $0 / 1$ & & \\
\hline 7193 & 4 & $\ldots$ & 50.5 & + & $\ldots$ & $0 / 1$ & $0 / 1$ & $0 / 0$ & $0 / 1$ & $0 / 0$ & $0 / 0$ & $1 / 0$ & $2 / 1$ & $0 / 1$ & 3 & 5 \\
\hline 7199 & 3 & 49.9 & 63.7 & + & $\mathrm{N}$ & $0 / 1$ & $0 / 1$ & $0 / 0$ & $0 / 1$ & $0 / 0$ & $0 / 1$ & $1 / 0$ & $2 / 1$ & $0 / 0$ & 3 & 5 \\
\hline 7192 & 5 & $\ldots$ & 58.2 & $\mathrm{~N}$ & $\mathrm{~N}$ & $\ldots$ & $0 / 1$ & $\ldots$ & $0 / 1$ & $0 / 0$ & $0 / 0$ & $0 / 0$ & $3 / 1$ & $0 / 0$ & $\ldots$ & $\ldots$ \\
\hline 7173 & 3 & 40.4 & 53.6 & $\mathrm{~N}$ & $\mathrm{~N}$ & $0 / 1$ & $0 / 1$ & $0 / 0$ & $0 / 1$ & $0 / 0$ & $0 / 1$ & $1 / 1$ & & $1 / 1$ & $\ldots$ & $\ldots$ \\
\hline 7259 & 8 & 47.0 & 55.6 & $N$ & $\ldots$ & $0 / 1$ & $0 / 1$ & $0 / 0$ & $1 / 1$ & $0 / 1$ & $0 / 1$ & $0 / 0$ & $2 / 1$ & $0 / 1$ & 3 & 7 \\
\hline 7270 & 3 & 53.2 & 62.9 & $\mathrm{~N}$ & $\mathrm{~N}$ & $0 / 1$ & $0 / 1$ & $0 / 0$ & $0 / 1$ & $0 / 0$ & $0 / 1$ & $0 / 0.5$ & $1 / 1$ & $0 / 1$ & 1 & 6.5 \\
\hline 7260 & 2 & 43.6 & 54.7 & $\mathrm{~N}$ & $\mathrm{~N}$ & $0 / 1$ & $0 / 1$ & $0 / 0$ & $0 / 1$ & $0 / 0$ & $1 / 1$ & $1 / 1$ & $1 / 1$ & $0 / 1$ & 3 & 7 \\
\hline 7271 & 2 & 41.5 & 46.7 & $\mathrm{~N}$ & $\mathrm{~N}$ & $0 / 1$ & $0 / 1$ & $0 / 0$ & $1 / 1$ & $0 / 0$ & $0 / 1$ & $1 / 0$ & $2 / 1$ & $0 / 1$ & 4 & 6 \\
\hline 7284 & 4 & 48.6 & 55.5 & $N$ & $\mathrm{~N}$ & $0 / 1$ & $0 / 1$ & $0 / 0$ & $0 / 1$ & $0 / 0$ & $0 / 1$ & $2 / 0$ & $1 / 1$ & $0 / 0$ & 3 & 5 \\
\hline 7246 & 3 & 39.4 & 46.0 & $\mathrm{~N}$ & $\mathrm{~N}$ & $0 / 1$ & $0 / 1$ & $0 / 1$ & $0 / 1$ & $0 / 0$ & $1 / 0$ & $0 / 0$ & $1 / 1$ & $0 / 1$ & 2 & 6 \\
\hline 7093 & 2 & $\ldots$ & $\ldots$ & $\mathrm{N}$ & $\mathrm{N}$ & $\ldots$ & $0 / 0.5$ & $\ldots$ & $0 / 1$ & $0 / 0$ & $0 / 0$ & $1 / 0$ & $1 / 1$ & $0 / 0.5$ & $\ldots$ & $\ldots$ \\
\hline
\end{tabular}

*..., appropriate sections or data not available; + , present; and $N$, not present. 
means were not different (6.6 versus 5.7$)$. When this score was compared with the RD score, there was no correlation. Of the four treated animals with scores of 8 and 8.5, the RD scores ranged from 4-7. Although the animal with an RD score of 9 had a lipid cell count of only 3, the animal with the lowest RD score had a lipid cell count of 2.5. In the control group, similar variations were seen: the animal with the best RD score (8) had the highest lipid cell count (7).

In four of the five animals with shrunken neurons in the hippocampus, counts of lipid-containing cells were also available. In two, the lipid cell count was 6 and 9 but in the other two animals it was only 2 and 3; thus, there did not appear to be a definite relation between these two parameters.

The degree of myelination could be evaluated in 11 treated and eight control animals and no difference was found in the total score (mean, 2.6 versus 2.3 ). In most sites there was no detectable myelin (score 0 ) and the lipid score was usually 1 , except in the fornix and the cingulum where sudanophilic lipids were usually absent. When myelination was detectable, the most common score was 1 , and the lipid count was also 1 . The most advanced myelination scores were in the internal capsule and optic tract, where the most common values were 1 and 2 . The highest lipid score of 2 occurred in these two sites in three animals. In the treated animals there was a tendency for the total lipid cell count to be higher in those with the lowest myelination score, but such a relationship was not obvious in the control animals.

\section{DISCUSSION}

This is the first neuropathologic report on the possible deleterious effects of glucocorticoids on the developing nervous system and on the sudanophilic lipid-containing glial cells in groups of experimental animals in which respirations were carefully supported, and in which the blood gases and chest $\mathrm{x}$-rays were carefully monitored. Most of the previous studies which reported harmful effects of glucocorticoids on developing animals were carried out in mice and rats, in which impaired central nervous system development occurred (24). Weichsel (25) reported immediate inhibitory effects on brain cell division and differentiation as determined by reduced DNA content, which was followed by latent or long-term physiologic and behavioral effects. More recently, similar studies have been carried out in subhuman primates. Fetal monkeys given $1.3 \mathrm{mg}$ dexamethasone via a maternal transabdominal percutaneous approach every other day for three doses beginning at $110 \mathrm{~d}$ gestation had significantly lower brain weights at $150 \mathrm{~d}(5)$. Johnson et al. (11) reported a significantly smaller median head circumference $(\mathrm{P}<0.005)$ in offspring of mothers treated with betamethasone $(2 \mathrm{mg} /$ day for $13 \mathrm{~d})$. The only microscopic description of brain findings is a single sentence in the report from Epstein et al. (6), who described "shrunken and densely stained cortical neurons with gliosis." The sites at which these changes were found were not specified, but such abnormal appearing neurons may be artifacts of fixation $(1,2,13)$. The mothers had been treated with two doses of betamethasone at 48 and $24 \mathrm{~h}$ before delivery at 135, 140, and $142 \mathrm{~d}$ gestation. It is difficult to believe that gliosis would develop so rapidly in these animals.

Reports in human infants have been even more variable $(5$, 24). Fitzhardinge et al. (8) found no difference in rate of growth and developmental quotient at 1 -yr follow-up in 12 infants who had been treated with hydrocortisone in the neonatal period, but, there was a significant lowering of the gross motor development in the treated group. At $5 \mathrm{yr}$ of age, survivors of the initial study of antenatal steroid administration (15) showed no deficit in cognitive development (16). Taeusch (24) and Weichsel (25) found no documentation of adverse effects from such treatment in humans.

We decided to examine the cerebellum and hippocampus in our animals because these regions are generally considered to be particularly vulnerable to a number of toxic and hypoxic conditions. Interestingly, the hippocampus was shown to be the site of intense localization of corticosterone, at least in the rat (4). We found shrunken neurons with darkly staining cell bodies and pyknotic nuclei in the hippocampus of three steroid-treated and two untreated animals, either in the foot-plate of the cornu ammonis or in the subiculum. These changes, therefore, do not appear to be attributable to the maternal steroid treatment alone. It is also not likely that hypoxia due to respiratory distress was responsible because we were able to maintain the $\mathrm{PaO}_{2}$ at greater than 40 Torr with the use of $100 \%$ oxygen in all animals and the RD scores in these animals were not particularly low; indeed, the RD was normal in one animal. Furthermore, other animals with even lower RD scores did not show similar changes.

The interpretation of dark shrunken cortical neurons has always been a problem in neuropathology. In human neuropathology, such neurons have traditionally been considered to reflect an "acute reaction," usually to anoxia or ischemia (10); however, identification of such acutely damaged neurons, whether due to hypoxia or to some toxic agents, is critically dependent on satisfactory fixation because some of these changes may be confused with certain types of artifacts (1). Koenig and Koenig (13) pointed out the frequent occurrence of shrunken cortical neurons, particularly near the cortical surface, with immersion fixation of the brain. Cammermeyer (2) described similar changes at sites of trauma during removal of the unfixed brain. He showed that such neuronal changes could be avoided if the brain were fixed in situ by vascular perfusion before its removal.

It appears that in our animals the presence of these altered neurons cannot be attributed either to the glucocorticoid administration to the mother or to the hyaline membrane disease in the infant. A similar reservation seems to be justified in the animals reported by Epstein et al. (6). Whether these changes are merely artifacts produced at the time of brain removal or are reflections of other toxic or hypoxic events is more difficult to determine, but the manner in which the brains were handled before fixation and the lack of correlation with RD scores or treatment with steroids strongly suggests that these changes are probably artifactual. Although oxygen delivery to these particular sites may have differed between animals, such regional blood flow measurements could not be carried out.

Sudanophilic lipid droplets in glial cells in the unmyelinated cerebral white matter of human infants have been viewed by some to be the result of perinatal hypoxia $(14,18,19)$ whereas others have regarded them as normal precursors of cerebral myelination $(17,26)$. The discovery of similar lipid accumulations in the brains of infant subhuman primates, made hypoxic and acidotic by manipulating the maternal blood pressure (22, 23), and in foci of spontaneous periventricular leukomalacia (21), appeared to support the first interpretation. But, further observations in a number of normal monkey fetal and infant brains indicated that sudanophilic lipid droplets are also a common occurrence in these animals (20). In the present group of treated animals, the total number of lipid-containing cells appeared to have an inverse correlation with the degree of myelination in the same sites.

Sudanophilic lipid-containing cells were present in some areas in all 18 animals in which appropriately stained sections were available. Although their total numbers varied, there was no correlation between the RD score and the numbers of lipidcontaining cells. If the lipid accumulations in these animals were due to hypoxic stress, as we had originally hypothesized $(22,23)$, we would have expected to find larger numbers of such cells in animals with the lowest RD scores. It should also be noted that there was no correlation between the numbers of these cells and the presence or absence of shrunken pyknotic neurons. Comparison of the number of lipid-containing cells to the degree of myelination could not be adequately assessed because the latter varied only between $0-1$ in most sites; however, in the optic tract, in which the degree of myelination ranged from $1-3$, the 
highest lipid score of 2 was found in two animals with a myelination score of 1 , and lower lipid scores of 0 or 1 were found when myelination was further advanced.

\section{CONCLUSION}

From all of these considerations, the following conclusions appear to be justified.

1) No acute adverse effect on fetal brain development can be found after the administration of glucocorticoids to pregnant subhuman primates in doses analogous to those given to prevent HMD in human infants.

2) Sudanophilic lipid droplets in glial cells in the unmyelinated cerebral white matter are not correlated with the degree of hypoxia in these animals, and may represent a normal stage in the formation of myelin as the scores in the optic tract suggest; however, determination of these values in animals of varying gestational ages is necessary before this point can be firmly established. Sudanophilic lipids may be found in glial cells in the developing subhuman primate cerebral white matter under two circumstances: in glial fatty metamorphosis and as a precursor of normal myelination. The distinction between these two circumstances may depend on the exact identification of the lipidcontaining cells.

\section{REFERENCES AND NOTES}

1. Brierley, J. B.: Cerebral hypoxia. In: W. Blackwood and J. A. N. Corsellis: Greenfield's Neuropathology. pp. 43-85 (Edward Arnold, London, 1976).

2. Cammermeyer, J.: The importance of avoiding "dark" neurons in experimental neuropathology. Acta Neuropathol., l: 245 (1961).

3. Chiffelle, R. L. and Putt, F. A.: Propylene and ethylene glycol as solvents for Sudan IV and Sudan Black B. Stain Technol. 26: 51 (1951).

4. DeKloet, E. R. and McEwen, B. S.: Differences between cytosal receptor complexes with corticosterone and dexamethasone in hippocampal tissue from rat brain. Biochim, Biophys. Acta, 421: 124 (1976).

5. de Lemos, R. A.: Glucocorticoid effect: organ development in monkeys. In: $\Upsilon$. D. Moore: Lung Maturation and the Prevention of Hyaline Membrane Disease. Report of the Seventieth Ross Conference on Pediatric Research. pp. 77-80 (Ross Laboratories, Columbus, Ohio, 1976).

6. Epstein, M. F., Farrell, P. M., Sparks, J. W., Pepe, G., Driscoll, S. G., and Chez, R. A.: Maternal betamethasone and fetal growth and development in the monkey. Am. J. Obstet. Gynecol., I27: 261 (1977).

7. Farrell, P. M. and Hamosh, M.: The biochemistry of fetal lung development. Clin. Perinatal., 5: 197 (1978).

8. Fitzhardinge, P. M., Eisen, A., Lejtenyi, C., Metrakos, K., and Ramsay, M.: Sequelae of early steroid administration to the newborn infant. Pediatrics, 53: 877 (1974).

9. Gilles, F. H., Leviton, A., and Dooling, E. C.: Developing Human Brain: Growth and Epidemiological Neuropathology. pp. 174-177 (Wright-PSG,
Littleton, Massachusettes, 1982).

10. Greenfield, J. G.: General pathology of the nerve cell and neuroglia. In: J. G. Greenfield, W. Blackwood, W. H. McMenemy, A. Meyer, and R. M. Norman: Neuropathology. pp. 1-66 (Edward Arnold, London, 1958).

11. Johnson, J. W. C., Mitzner, W., London, W. T., Palmer, A. E., and Scott, R.: Betamethasone and the rhesus fetus: multisystemic effects. Am. J. Obstet. Gynecol., 133: 677 (1979).

12. Kessler, D. L., Truog, W. E., Murphy, J. H., Palmer, S., Standaert, T. A., Woodrum, D. E., and Hodson, W. A.: Experimental hyaline membrane disease in the premature monkey: effects of antenatal dexamethasone. Am. Rev. Resp. Dis., 126: 62, (1982).

13. Koenig, R. S. and Koenig, H.: An experimental study of post-mortem alterations in neurons of the central nervous system. J. Neuropathol. Exp. Neurol., 11: 69 (1952).

14. Leech, R. W. and Alvord, E. C., Jr.: Glial fatty metamorphosis. Am. J. Pathol., 74: 602 (1974).

15. Liggins, G. C.: Prenatal glucocorticoid treatment: Prevention of respiratory distress syndrome. In: T. D. Moore: Lung Maturation and the Prevention of Hyaline Membrane Disease. Report of the Seventieth Ross Conference on Pediatric Research. pp. 97-105 (Ross Laboratories, Columbus, Ohio, 1976).

16. McArthur, B. A., Howie, R. N., Dezoete, J. A., and Elkins, J.: Cognitive and psychosocial development of 4 year old children whose mothers were treated antenatally with betamethasone. Pediatrics, 68: 638 (1981).

17. Mickel, H. and Gilles, F. H.: Changes in glial cells during human telencephalic myelinogenesis. Brain, 93: 337 (1970).

18. Schwartz, P.: Virchow's congenital encephalomyelitis of the newborn: a basic but neglected problem. Arch. Pediatr., 75: 175 (1958).

19. Schwartz, P.: Birth Injuries of the Newborn; Morphology, Pathogenesis, Clinical Pathology and Prevention. (Hafner Publishing Co., Inc., New York, 1961).

20. Sumi, S. M.: Periventricular leukoencephalopathy in the monkey. Arch. Neurol., 31: 38 (1974).

21. Sumi, S. M.: Sudanophilic lipid accumulation in astrocytes in periventricular leukomalacia in monkeys. Acta Neuropathol., 47: 241 (1979).

22. Sumi, S. M., Leech, R. W., Alvord, E. C., Jr., Parer, J., Eng, M. and Ueland, K.: Accumulation of sudanophilic lipids in the cerebral white matter of premature primates. An experimental inquiry into the pathogenesis of the Virchow-Schwartz-Banker-Larroche lesion. J. Neuropathol. Exp. Neurol. 31: 183 (1972).

23. Sumi, S. M., Leech, R. W., Alvord, E. C., Jr., Eng, M., Ueland, K.: Sudanophilic lipids in unmyelinated primate cerebral white matter following intrauterine hypoxia and acidosis. Proc. Assoc. Res. Nerv. Ment. Dis., 51: 176 (1973).

24. Taeusch, H. W., Jr.: Glucocorticoid prophylaxis for respiratory distress syndrome: a review of potential toxicity. J. Pediatr., 87: 617 (1975).

25. Weichsel, M. R., Jr.: Therapeutic use of glucocorticoid hormones in the perinatal period: potential neurological hazards. Ann. Neurol., 2: 364 (1977).

26. Wohlwill, F.: Zur Frage der sogenannten Encephalitis congenita (Virchow). I Über normale und pathologische Fettkörnchenzellbefunde bei Neugeborenen und Säuglingen. Z. Gesamte Neurol. Psychiatr., 68: 384 (1951).

27. The authors thank Dr. Ellsworth C. Alvord, Jr. for his helpful criticism and comments.

28. Requests for reprints should be addressed to: Dr. S. M. Sumi, Laboratory of Neuropathology, RJ-05, University of Washington School of Medicine, Seattle, Washington 98195.

29. Received for publication March 31, 1983.

30. Accepted for publication July 14,1983 . 